\title{
How the Reader Matters. Autobiographies of Childhood for Young Readers
}

\author{
Helma van Lierop-Debrauwer
}

Tilburg University

\section{ABSTRACT IN ENGLISH}

In the 1990s, autobiographies of childhood were one of the most important publishing trends. These autobiographies challenge the Romantic notion of childhood, thus contributing to the contemporary societal debate about children and childhood in crisis. Taking into consideration that ideas about children and childhood are at the heart of children's literature, it is remarkable that autobiographies of childhood for young readers go unnoticed in the discussion.

On the basis of Hoe moet dat nu met die papillotten? (1993), written by Dutch author Rita Verschuur, I argue that the image of children in this text for young readers is more in line with the Romantic conception of childhood innocence than is the notion of children in autobiographies for adult readers.

\section{SAMENVATTING IN HET NEDERLANDS}

In de jaren negentig is er een opvallende toename van autobiografieën over de kindertijd voor volwassen lezers. In deze autobiografieën wordt de Romantische notie van het kind ter discussie gesteld. Hierdoor functioneren deze teksten in het hedendaagse maatschappelijk debat over de zorg over en voor kinderen. Wanneer men in aanmerking neemt dat ideeën over kinderen en de kindertijd de kern vormen van kinder- en jongerenliteratuur, dan is het opmerkelijk dat er tot op heden geen aandacht is geweest voor autobiografieën over de kindertijd voor jonge lezers. 
In dit artikel betoog ik op basis van Hoe moet dat nu met die papillotten? (1993), een autobiografisch verhaal van de Nederlandse auteur Rita Verschuur, dat het beeld van kinderen in deze tekst voor jonge lezers meer kenmerken heeft van het Romantisch notie van het kind dan de kindbeelden in autobiografieën voor volwassen lezers.

Keywords: autobiographies of childhood, children's and young adult literature, imagining childhood

\section{INTRODUCTION}

In Contesting Childhood (2010) Australian researcher Kate Douglas argues that autobiographical narratives of childhood experiences are one of the most important publishing trends in the 1990s and 2000s. These books were published against the background of an intense socio-cultural preoccupation with the child and with childhood in crisis at the turn of the Millennium. Focusing on the two most common motives for remembering childhood, trauma and nostalgia, Douglas explores how these autobiographies of childhood challenge the notion of childhood as a time of innocence. For the most part, Douglas limits herself to autobiographies of childhood written by adult authors and intended for adult readers. In her conclusion, Douglas notices 'an absence of published autobiography written by children or young adults' (172). Acknowledging the need to include voices of young people in the genre, she briefly explores life writing by adolescents on the Internet. Together with Anna Poletti, Douglas continues this line of research in Life Narratives and Youth Culture (2016) which explores various life writing practices by young writers, however without paying specific and systematic attention to the intended audience of these narratives. Their focus is on 'the practices of authorship and textuality behind texts' (9).

Taking into consideration that fundamental ideas of children and childhood are at the heart of the study of children's literature, it is remarkable that Douglas does not discuss the construction of childhood in autobiographies of childhood experiences written by adult authors and aimed at young readers. Therefore, this form of life writing will be the focus of my article. I will analyze one particular case study: Hoe moet dat nu met die papillotten? (1993; What about my curls?), which is the first book in a series of autobiographical narratives of childhood experiences in the 1940s and 1950s, written for young readers by Dutch children's book author Rita Verschuur. The book appeared against the same cultural background as the autobiographies Douglas discusses. Based on observations gathered from close reading this case, I will argue that because of the presumed 
life experience of the intended child reader, this autobiography for young readers creates an image of children and of childhood that is much more in line with conceptions of childhood innocence than the construction of this stage of life in the life narratives for adult readers scrutinized in Douglas' study.

To make a comparison possible between Verschuurs autobiography for child readers and those for an adult readership, I will first present the main conclusions Douglas draws in Contesting Childhood.

\section{KEY-ISSUES IN EXPLORING AUTOBIOGRAPHIES OF CHILDHOOD FOR ADULT READERS}

Douglas discusses autobiographies of childhood from different perspectives: 'as memory practice, as discourse on childhood, as literature, and/ or as an overtly political "call to action"” (170). The most important trend she observes in autobiographical writing about childhood experiences in the 1990s and 2000s is the remarkable increase in traumatic autobiographies by first-time authors (171). Many of these narratives use everyday language, thus challenging literary conventions and being often explicitly didactic in their call for political action. Writing the traumatic childhood experiences down is mainly fueled by "a need to "write back" to mythologies of childhood that have been prevalent in the twentieth and twentyfirst centuries' (41), in particular to the idea of childhood as a 'golden age' (41). In this respect, autobiographies of childhood function as representations of past childhoods 'as much as they reveal modern preoccupations about childhood' (42). For the past twenty-five years childhood has been a highly contested area, the child being at the center of many political and ideological debates (4). Although Douglas nowhere explicitly discusses the origins of the notion of a happy and innocent childhood, she obviously refers to the Romantic conception of this stage of life, discussed by among others Natov (2003) and Kümmerling-Meibauer (2008). The Romantic child was conceptualized in the second half of the eighteenth century and the beginning of the nineteenth century, by Rousseau, Blake and Wordsworth as 'an embodiment of natural goodness' (Natov, 4), innocence and creativity. Innocence is considered to be a positively valued lack of knowledge and experience, intricately connected with a fresh and unique worldview, determined by imagination and an absence of rationalization. The Romantic image of childhood is in many ways the counterpart to the conceptualization of the child in the Enlightenment era. Whereas pedagogues in the latter period regarded the child as an incomplete human being who should do its best to reach the ideal 
of adulthood as soon as possible, people like Rousseau, appreciated the Romantic child as a full individual with its own needs and emotions. In the Romantic notion of childhood and adulthood, the ideal adult was the one who had best retained the child in him- or herself (Ghesquière et al., 25).

Like the authors of the autobiographies in Douglas' study, children's literature scholars agree that childhood is in crisis and that the Romantic concept of childhood is no longer tenable in today's society. However, Reynolds observes a discrepancy between these scholarly discussions about childhood and the notion of childhood created by adult authors in children's books, at least in Great Britain, because the child image in British texts for young readers is still 'effectively a monolithic and unreconstructed version of the "Romantic Child" (8).

In the autobiographies of traumatic childhoods that Douglas discusses, the engagement with the Romantic trope of innocence already starts with the covers. Although the photos on them often strongly allude to the happy and playful child, the book titles tend to be more ambiguous. They challenge 'the photographic image and its connotations of innocence' and function 'as ominous forewarnings of the text's content' (63) which most of the time contest the Romantic idea of a happy childhood, such as Bad Blood. A Memoir (Sage 2000), Out of Darkness (Knight 1998) and Shadow Child (Fraser 1998).

In her study, Douglas also examines issues of authenticity and voice, two key concepts in life writing studies. The two terms are related to what she calls 'scripts for remembering' (84). With respect to voice, Douglas zooms in on the distance between the self of the adult writer and his or her former child self and on the tension between individuality and representativeness. With respect to the former she argues that dialogism in the Bakhtinian sense of the word, is inherent to autobiographical narratives of childhood, being a dialogue between an adult self and a child self which mainly occurs in three ways: 'via the all-knowing, retrospective adult speaking for the child, within the juxtaposition of the adult and child voices, and in the use of the naive child voice' (89). According to Douglas most autobiographies for adult readers share the overt intervention of the knowing adult. In particular authors of traumatic autobiographical narratives 'emphasize that it is only through the adult voice, and the particular contemporary cultural environment they find themselves in, that they are able to recite their narratives' (110). Because of the distance between traumatic childhood experiences and the moment of writing, 'autobiography has become a mechanism for mediating between the past and the present, between the child and the adult self, and between trauma and healing' (110-111). As autobiographies for young readers are 
mainly written by adults, the presence or absence of the adult voice will be an important point of comparison between narratives for children and those for adult readers examined by Douglas.

The tension between individuality and representativeness occurs when the autobiographer not only presents him- or herself as an individual, speaking for his or her child self, but also uses his life narrative for representing people with a comparable background and dealing with the same problems. This dual aim once more underlines the political character of many of these autobiographies.

Authenticity, having to do with reliability and being trustworthy, is analyzed by Douglas mainly in relation to traumatic autobiographies. She notices that autobiographical narratives of traumatic childhood experiences are often fragmented in their representations of the past, on the one hand due to the inaccuracy of memory in general, on the other because of the mechanism of forgetting which is characteristic of trauma. Writers deal with their traumatic experiences in different ways: some explicitly acknowledge their memory loss, whereas others do not, thus influencing the extent to which readers perceive these autobiographical narratives as authentic. For adult readers, Douglas states, a fragmented representation of the past and an autobiographical voice which explicitly stresses the limitations of memory are considered to be important devices in convincing readers of the authenticity of the narrative.

In my analysis of Hoe moet dat nu met die papillotten? I will discuss how the issues that Douglas brings to the forefront, are represented in this autobiographical narrative for children.

\section{AUTOBIOGRAPHICAL WRITING FOR YOUNG READERS ABOUT CHILDHOOD IN WARTIME}

Although autobiographical writings for young readers are not published in the same number as their counterparts in adult literature, they are definitely there, the main motives for writing also being nostalgia and trauma. With regard to autobiographical narratives with traumatic themes, those about wartime memories immediately catch the eye, the earliest and most famous example being of course Anne Frank's Het Achterhuis (1947; The diary of a young girl). Since the first publication of her diary in 1947 numerous other diaries and autobiographies on childhood experiences during the Second World War have been published, as well as narratives telling about children growing up in other wars, for example Zlata's Diary: A Child's Life in Wartime Sarajevo (1994) by Zlata Filipovic about the Balkan War in the 1990s. Although these two examples were written by young, 
first-time authors, ${ }^{1}$ many other war autobiographies are written by wellknown adult authors. Famous international examples are the autobiographical picturebooks about the Second World War and the Cold War made by well-known children's book authors such as Tomi Ungerer (Tomi: A Childhood under the Nazi's, 1998) and Peter Sís (The Wall: Growing up behind the Iron Curtain 2007), to name just a couple. In Dutch children's literature, autobiographical narratives about the Second World War, have been published since the 1960s. Authors of these books obviously needed time to cope with their war experiences as a child or adolescent before they could write them down for young people. Some of them explicitly state that they would rather have kept silent, but nevertheless speak about the past out of their concern for the children and adolescents of today (De Vries 1990). Such pedagogic-didactic motives have long been an issue when it comes to writing auto/biographical texts for children (Natov 1986, and Karst 1993).

Notwithstanding the fact that the notion of childhood is central to (the study of) children's literature, research on the construction of childhood in autobiographies for young readers so far has been limited and fragmented. Hitherto, research on these texts has been embedded in studies of other forms of (live) narratives and/or without a specific focus on images of childhood in autobiographical writings for children. ${ }^{2}$ Two studies are of interest here, because they deal with the representation of the Holocaust in both fiction and auto/biographies in relation to the child reader. Even though my case study is not about the Holocaust in itself, I glean useful insights from their observations. In her discussion of children's books representing the Holocaust, Lydia Kokkola (2003) in one chapter deals with life writing and with how this 'young adult literature signals the fiction/faction boundary' (p. 85) and 'whether inexperienced readers are able to recognize fictional elements in works written by witnesses' (p. 13). Although images of the child underlie Kokkola's exploration of the reader's ability to discriminate between fictional and factual elements, she does not explicitly address them. In contrast, Vloeberghs (2008) does pay distinct attention to constructions of childhood and children in her study on Holocaust literature for children, but she does not make a specific distinction between fiction and auto/biographies. Vloebergs discusses the dilemma of the impossibility of writing for children about the atrocities of the Holocaust and the pedagogical impulse to inform them about what happened in the past (174-175). The inhuman cruelty of the Holocaust strongly contrasts with the idea of an unproblematic, sound world children's literature traditionally conveys. Vloeberghs observes that the representation of the Holocaust is therefore on three levels fundamentally different from that in adult literature: the 
epistemological level (knowledge), the psychological level (emotions) and the ethical level (agency) (175). Because you cannot expect from young readers that they have the knowledge to understand what happened, many children's books about the Holocaust give factual information, for example by including maps and timelines, and by an explicit description in the paratext of the relationship between the story and reality and/or the connection between the author and the main character (176). Authors seek to find a balance between historical credibility and fictionality. With respect to the psychological level writers use strategies to protect young readers from the harsh reality, such as leaving out details about the cruelties that took place. The ethical level is related to the message authors want to give to young readers about human nature (185). Because children's literature has traditionally been characterized by a fundamental optimism and confidence in human values, authors writing about the Holocaust for young readers often choose a strong identification figure and write a narrative that keeps the promise of survival and a life after war, however often accompanied by the message that nothing will ever be the same (191).

In what follows I will concentrate on Hoe moet dat nu met die papillotten?, as said the first book of a Dutch series on childhood experiences in the 1940s and 1950s, during the Second World War and beyond. The books, marketed to children from the age of ten upwards, are written by Rita Verschuur (also known as Rita Törnqvist) who is a well-known children's book author in the Netherlands. Her autobiographical books have won several important children's literature awards and they got positive reviews. Many reviewers appreciated in particular the consistently maintained child perspective (see among others Van Duin 1993). Hoe moet dat nu met die papillotten? tells about the author's life experiences between May 1940 and May 1945. As said, the story is not about the Holocaust, but about wartime experiences of a non-Jewish girl.

In my analysis, I will follow Douglas in her reflection on autobiographical narratives of childhood as part of contemporary discourse on childhood. What childhood is being constructed and how, and what does this say about the child reader implied in the text? To answer these questions, I will also make use of the insights provided by Kokkola (2003) and Vloeberghs (2008).

\section{'THE EARLIEST MEMORIES OF MY LIFE': RITA VERSCHUUR'S CHILDHOOD IN WARTIME}

The first thing that strikes the reader about Hoe moet dat nu met die papillotten? is that the book has no photo on the cover. Instead, there is a drawing 
on it, which is common for fictional books. The picture shows a male adult and a child on a bike, the adult helping the child to cross a bridge. The image seems to refer to the notion of the child as innocent and in need of assistance and protection by the more experienced adult. The title of the book at first sight sounds mysterious, but it does not affect the element of innocence implied in the image as is often the case with the autobiographies Douglas discusses.

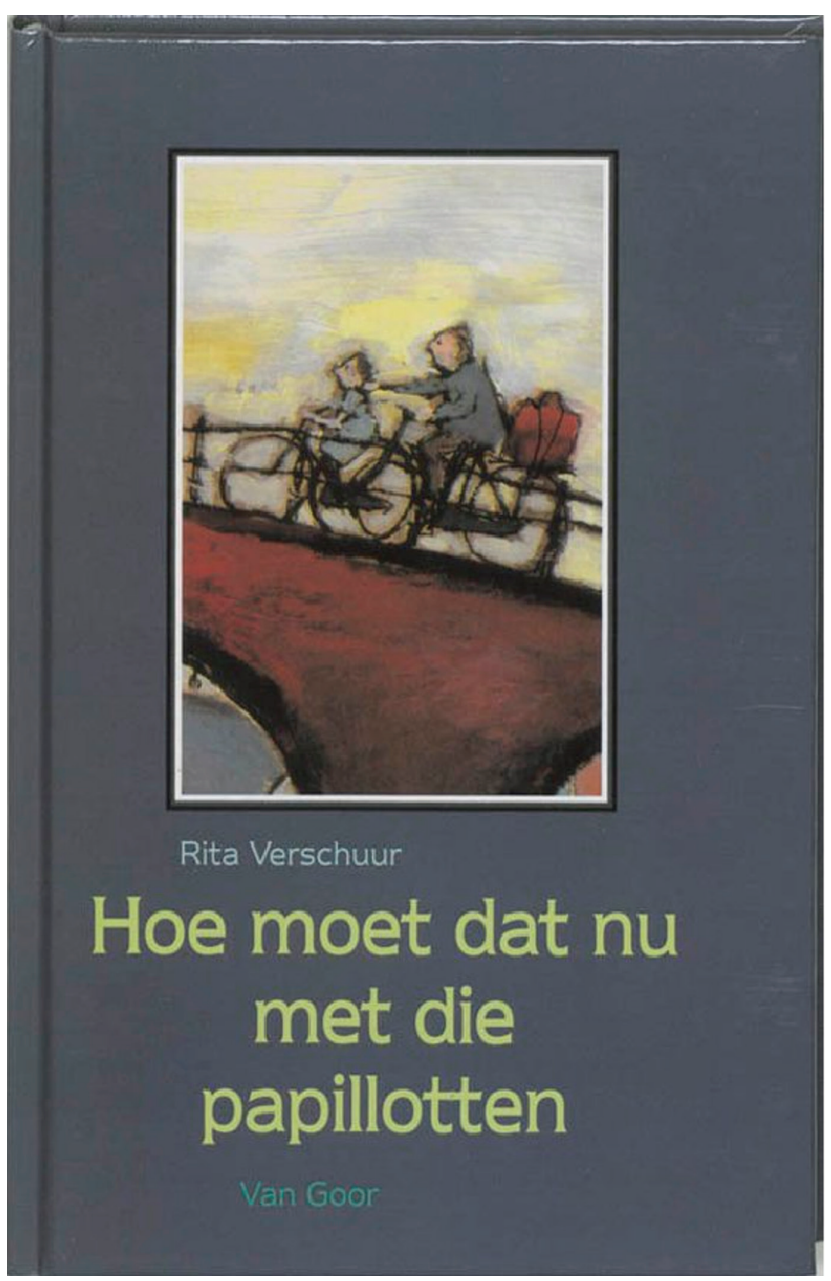

The cover of Hoe moet dat nu met die papillotten (1993). 
The text on the back cover explicitly refers to the book being memories of a childhood between 1940 and 1945. However, together with a few lines at the beginning, before the actual narrative starts, these are the only explicit references to the book being an autobiography of childhood. This stands in contrast with the observation by Vloeberghs that children's authors of Holocaust narratives, put much effort into establishing a relationship between the author and the protagonist and in explaining the relation between the narrative and historical reality (176). Maybe Verschuur considered this relationship to be self-evident for the reader as the author and protagonist have the same name. The sentences at the beginning tell the reader that the story consists of the earliest memories the author has of her own life. There are no signals that Verschuur has any didactic motives for writing her life story, such as speaking on behalf of other children who grew up during the war or writing out of a concern for children of today like other authors of autobiographical narratives mentioned earlier. Hoe moet dat nu met die papillotten? is a life narrative of one particular child.

In the narrative itself, the adult self of the author is almost completely hidden behind the story, which foregrounds the naïve voice of little Rita who is four years old when the war begins. There is also no reference to the process of remembering. Whereas in autobiographies for adults the voice of an adult author explicitly discussing the loss of memories is considered to be a marker of authenticity, in autobiographies for young readers, the naïve child narrator might be interpreted as a gesture of authenticity for the child reader. However, the adult author does seem to interfere with the child's voice a few times. The narrative starts when the war begins and the first German aircraft cross the Netherlands. Rita's neighbors come together to discuss the situation. For little Rita, it seems as if everybody has become friends and she says to her mother: 'I wish it could always be war. Mommy looks at me a little bit strangely. I don't understand why. I am four years old' (9). The addition of Rita's age as an explanation for her ignorance signals the presence of an adult narrator. Why her mother reacts as she does, is not explained. This absence of an explanation implies a child reader who has more knowledge of the war than Rita does to understand the situation. The author expects that the reader already knows that war is not something you wish for.

When the narrative continues, the naïve child voice is most of the time maintained. Everything is presented as if it happened only recently, rather than more than fifty years before the publication of the book. The events are written down in very short chapters, almost like entries in a diary, which underlines the suggestion of immediacy. The child voice 
is created through short, simple and clear sentences. The adult self has put herself back in the shoes of her child self, seldom explaining what a four-year-old child observes but does not understand. The young age of the child self and the fact that the adult self is most of the time hidden, have consequences for the representation of war as was already clear in the aforementioned quotation. Only after she has grown older-at the end of the war she is nine years old-she learns about the dark sides of wartime, for example when she has to practice at school what to do when there is a fire alarm, when three children do not return to school after the capitulation, and when her father has to hide from German soldiers during raids: 'Daddy is hiding somewhere in our house. I don't know where. Children shouldn't know too much, mother says. But when the Fritz are in the house, I am terrified' (81). Rita is eight years old here. The derogatory term for the Germans might be an intervention of the adult self, but Rita may also just be imitating adults in her environment. Here again, the reader implied in the text is expected to know why Rita is so afraid because it is not explicitly worded. That the story is told from young Rita's perspective is the main explanation for the scarcity of historical facts in this book and the absence of details about what happened. The paucity of factual information once more stands in contrast to Vloeberghs' observation that authors of historical youth novels in general and narratives about the Holocaust for young readers in particular, feel a strong need to inform their readers about the relation between the story and historical reality (176). In the later books about her childhood, ${ }^{3}$ when Rita is twelve and older, she becomes more aware of the horrors of war. In this first book, besides the facts just mentioned, there are only a few other moments in this first book where the author integrates historical information in the storyline, one of them being uncle Jan visiting Rita's parents after the capitulation of the Dutch army in May 1940. In Rita's reflection on uncle Jan fighting against the Germans only 'a few days' (10), the child and the adult voice mingle. While young Rita was excited about the beginning of the war, here the adult voice interferes with the child voice by stating only a couple of days later that war is one of the worst things that can happen to people, because 'the Germans have now occupied the country' and 'they can do with us what they want' (10). Moreover, in this fragment, the implied reader is again expected to bring in more knowledge than Rita has, and to understand that the Dutch army surrendered five days after the war began.

Despite these references to the harsh reality, war is most of the time just another life experience for young Rita, and not even the hardest one, because she is protected against these external threats by her father, her 
stepmother and her grandparents who try to keep her as ignorant and innocent as possible and who let her enjoy life as much as possible in these hard times. This idea of childhood ties in with Douglas' aforementioned notion of childhood as 'a golden age' (41). One example of the adult strategies used to distract little Rita is her granddad-without her knowing this-throwing little greenish-blue stones between the gravel in the yard every time his granddaughter comes to visit him. He explains to the little girl that these stones are called turquoises and that they are very special. Rita, six years old at the time, collects them and enjoys that very much. On the last page of the book she visits her grandparents again, just after the war has ended. She is nine years old now. The first thing she does is search for the little stones, but she does not find any. Then she suddenly realizes that her granddad must have scattered them among the gravel for her amusement, and she concludes that she is old enough now to do without what she calls 'such jokes' (126). This development reveals an image of the child which makes a distinction between very young children who need to be protected from the hardships of life and older children who are thought to be resilient enough to cope with catastrophes. As the book is intended for readers from the age of ten upwards, the fact that the reader is often expected to know more than Rita fits this child conception.

The most traumatic experience during wartime is her parents' divorce. Her mother moves to Amsterdam when Rita is eight years old and her father remarries. She visits her mother every now and then, but these visits are often disappointing because her mother is more concerned with dating Canadian soldiers than she is with taking care of Rita. However, the love of her father, her grandparents and her stepmother compensates for her sadness about her own mother's attitude. The title of the book is an implicit reference to the divorce. When her father's new marriage is planned Rita worries about her hair: she wants to have curls, but the only one who can make them in the right manner is her mamma who lives in Amsterdam. In this way, Rita brings her grief about the divorce down to a size she can deal with. The image of the child in the text and that of the child reader constructed here is one that expresses care for the emotional vulnerability of children. The larger pain underneath the worries about her hairstyle, is not verbalized. Compared to Verschuur's biographical narrative about her mother, Het geheim van mijn moeder (2008; My mother's secret) for adult readers, this autobiographical book for young readers is far more implicit about the difficult relationship between Rita and her mother. 




The cover of Het geheim van mijn moeder (2008).

The cover of Het geheim van mijn moeder is very much like the covers that Douglas discusses. On the front cover there is a photo of little Rita, embracing her mother, both smiling and looking happily into the camera. While this photo alludes to a happy and innocent childhood, the title challenges this romantic notion by referring in a somewhat cryptic manner to a possible threat. Reading the book, we find out that the secret is that Rita's mother never really cared for her. Her mother's neglect is 
presented explicitly by the adult author. The main reason for the differences between the children's book and the novel for adults is presumably that the children's book is told from a naïve child perspective. Young Rita is loyal to her mother and she simply cannot or does not want to believe her mother is neglecting her. In the adult novel Rita is a grown-up woman. Looking back on her life and taking into account the difficult relationship with her mother later in life, she interprets her childhood experiences in a far more negative way than she did in the children's book. In spite of the traumatic experiences and threats from outside and within the family that the child is confronted with, Hoe moet dat nu met die papillotten? holds on to the romantic notion of childhood of innocence and vulnerability, whereas the adult book undermines it. However, the romantic view is not the only childhood image present in the children's book. The book also expresses an image of the child as resilient and competent, because besides being protected by adults, Rita is also a child with agency who often finds her own solutions to deal with problems she encounters, such as the rivalry between her mother and her stepmother. To a certain extent this image of the resilient child nuances the romantic notion of the vulnerable child. This notion of the child as having agency and being resilient coincides with what Vloeberghs calls the ethical level of Holocaust narratives: the potential of the child for a better, more optimistic future.

\section{CONCLUSION}

On the basis of my analysis of Hoe moet dat nu met die papillotten? I think it is possible to draw a conclusion about the construction of childhood in this book and of the child reader implied in the text. A comparison of the observations gleaned from close-reading Verschuur's autobiographical narrative with Douglas' conclusions makes it possible to answer the question how the reader matters in how childhood is depicted in this autobiography of childhood for young readers. Like the autobiographies of childhood for adult readers that Douglas mentions, Verschuur's autobiography challenges the unitary idea of 'the child.' The book is written from the perspective that every child is an individual, coping in his or her own way with the problems he or she encounters. However, compared to the autobiographical narratives Douglas discusses, the life narrative by Rita Verschuur, does not contest the romantic concept of the innocent child as much as the autobiographies for adults do, both in its representation of the protagonist and in the figure of the child reader that emerges from these representations. The romantic idea is only slightly adapted by combining innocence with competence and focusing on resilience 
instead of vulnerability. As said, the image of childhood constructed in the text makes a distinction between younger and older children. Older children, including the intended reader from the age of ten upwards, are considered to be more resilient than the very young and they are also expected to have more knowledge that the younger protagonist.

With respect to the form, the autobiographical narrative written by Rita Verschuur, more so than autobiographies of childhood for adults which are often written in everyday language (Douglas, 171), makes use of literary strategies such as a diary style to evoke the suggestion of immediacy and short, straightforward sentences to create a child voice. Moreover, most of the time, the author does not have the pedagogical impulse to integrate historical information that does not match with the perspective of a four-year-old child. The main consequence of this is that Verschuur's narrative is less explicitly didactic than the autobiographies discussed by Douglas, and the autobiographical narratives for young readers mentioned by De Vries, which is interesting, because it turns traditional expectations with respect to both adult and children's literature upside down. It is often argued that the explicit pedagogical or didactic intention of children's books is what distinguishes them from adult literature. Verschuur's autobiography of childhood is not a carefully documented representation of the Second World War, nor a book that was primarily written out of an actual relevance, i.e. out of a didactic need to pass on the message that a war like this should never happen again. Hoe moet dat nu met die papillotten? is written out of a personal need felt by the author to recall her own childhood. As such, the book fits in with developments in children's literature since the 1990s where authors and critics of children's books consider the pedagogical function to be of less importance than the aesthetic function, meaning that they value the literary form more than the message the text conveys.

\section{WORKS CITED}

\section{Primary works}

Filipovic, Zlata. Zlata's Diary. A Child's Life in Wartime Sarajevo. London: Penguin Books, 1994. Frank, Anne. Het Achterhuis (The diary of a young girl). Amsterdam: Contact.

Fraser, Rosalie. Shadow Child. A Memoir of a Stolen Generation. Sydney: Hale \& Iremonger, 1998.

Knight, Ivor A. Out of Darkness. Growing Up with the Christian Brothers. Fremantle: Fremantle Art Centre Press, 1998.

Sage, Lorna. Bad Blood. A Memoir. London: Fourth Estate, 2000.

Sís, Peter. The Wall. Growing Up behind the Iron Curtain. New York: Farrar, Straus and Giroux, 2007.

Ungerer, Tomi. Tomi. A Childhood under the Nazis). Niwot: Robert Rinehart, 1998.

Verschuur, Rita. Hoe moet dat nu met die papillotten (How about those curls). Amsterdam: Van Goor, 1993.

Verschuur, Rita. Het geheim van mijn moeder (My mother's secret). Amsterdam: Cossee, 2008. 


\section{Secondary works}

Bradford, Clare. Unsettling Narratives. Postcolonial Readings of Children's Literature. Waterloo: Wilfries Laurier University Press, 2007.

Davis, Rocio. "Metanarrative in Ethnic Autobiography for Children. Laurence Yep's "The Lost Garden" and Judith Ortiz Cofer's "Silent Dancing"." Multi-Ethnic Children's Literature 27.2 (2002): 139-156.

Davis, Rocio. "Asian American Autobiography for Children. Critical Paradigms and Creative Practice." The Lion and the Unicorn 30.2 (2006): 185-201.

Douglas, Kate. Contesting Childhood. Autobiography, Trauma, and Memory. New Brunswick and London: Rutgers University Press, 2010.

Douglas, Kate and Anna Poletti. Life Narratives and Youth Cultures. Representation, Agency and Participation. London: Palgrave Macmillan, 2016.

Duin, Lieke van. "Argeloos in de oorlog (Naive in the war)." Trouw, 29 September 1993, n.p.

Ghesquière, Rita, Vanessa Joosen en Helma van Lierop-Debrauwer. "Inleiding. Geschiedenis van de jeugdliteratuur in vogelvlucht (Introduction. History of children's literature in a nutshell)." Eds. Ghesquière, Rita, Vanessa Joosen en Helma van Lierop-Debrauwer. Een land van waan en wijs. Geschiedenis van de Nederlandse jeugdliteratuur (A land of illusion and wisdom. History of Dutch children's literature). Amsterdam/Antwerpen: Atlas Contact, 2014.

Heijden, Ingrid van, and Helma van Lierop-Debrauwer. "A Threefold Hybridity. Picturebook Art Fantasies as Life Writing." European Journal of Life Writing III (2014): 63-81. Doi: http://dx.doi.org/10.5463/ejlw.3.119.

Karst, Theodor. "Autobiographien - Lektüre für die Jugend. Überlegungen zur didaktische Bedeutung von literarischen Lebens- und Lesemodellen.” Beiträge Jugendliteratur und Medien 4 (1993): 144-152.

Kokkola, Lydia. Representing the Holocaust in Children's Literature. New York and London: Routledge, 2003.

Kümmerling-Meibauer, Bettina. "Images of Childhood in Romantic Children's Literature." Eds. Gerald Gillespie, Manfred Engel, and Bernard Dieterle. Romantic Prose Fiction. Amsterdam: Benjamins, 2008. 183-203.

Kümmerling-Meibauer, Bettina. "Remembering the Past in Words and Pictures. How Autobiographical Stories Become Picturebooks." Eds. Colomer, Theresa, Bettina Kümmerling-Meibauer and Cecilia Silva Díaz. New Directions in Picturebook Research. New York and London: Routledge, 2010. 205-216.

Lierop-Debrauwer, Helma van. "Between Reality and Fiction. Der Gelukvinder by Edward van de Vendel and Anoush Elman as Life Writing for Adolescents." Eds. Glasenapp, Gabriele, Dettmar, Ute, and Bern Dolle Weinkauff. Kinder- und Jugendliteraturforschung international. Ansichten und Aussichten. Frankfurt am Main: Peter Lang, 2014. 357-369.

Natov, Roni. "The Truths of Ordinary Lives. Autobiographical Fiction for Children." Children's Literature in Education 17.2 (1986): 112-125.

Natov, Roni. Poetics of Childhood. New York and London: Routledge, 2003.

Reynolds, Kimberley. "Introduction." Ed. Reynolds, Kimberley. Children's Literature and Childhood Performances. London: Pied Piper Publishing, 2003. 3-10.

Schrijvers, Marloes. "Achieving a Shared Understanding of Life Artists' Reflections on their Constructions of the Past and the Self in Traumatic and Nostalgic Autobiographical Picturebooks." European Journal of Life Writing III (2014): 121-154. Doi: http://dx.doi. org/10.5463/ ejlw.3.137.

Vloeberghs, Katrien. "Kinder- en jeugdliteratuur over de Holocaust. Een ontmoeting tussen werkelijkheid en weergave (Children's literature about the Holocaust. An encounter between reality and representation)." Eds. Joosen, Vanessa, and Katrien Vloeberghs. 
Uitgelezen jeugdliteratuur. Ontmoetingen tussen traditie en vernieuwing (Excellent children's literature. Encounters between tradition and renewal). Leuven and Den Haag: Lannoo Campus and Biblion, 2008. 171-196.

\section{ABOUT THE AUTHOR}

Helma van Lierop-Debrauwer is Professor of Children's Literature at Tilburg University in the Netherlands. She is the coordinator of the Children's and Adolescent Literature Master's program at this university. She is a member of the editorial board of Literatuur zonder leeftijd, the only academic journal on children's literature in the Netherlands. Her research interests are adolescent literature, life writing and the relationship between children's literature and age studies.

\section{NOTES}

1 Discussed by Douglas and Poletti (2016) as iconic examples of war diaries written by young people. With respect to Zlata's Diary, Douglas and Poletti also notice that this book was marketed to a readership of 'young adult readers and adult readers alike' (72).

2 Recently there have been studies on the synergy between words and pictures in picturebook life writing (Kümmerling-Meibauer 2010; Schrijvers 2014; Van der Heijden and Van Lierop-Debrauwer 2014), a study on fictional and autobiographical texts of native writers in Australia (Bradford 2007), and small-scale studies on ethnic autobiographies for young readers (Davis 2002, 2006 and Van Lierop-Debrauwer 2014).

3 After the first book, she wrote seven more. 